\title{
IDENTIFICATION OF RISK: AN EMPIRICAL EVIDENCE
}

doi: 10.2478/czoto-2021-0019

Date of submission of the article to the Editor: 20/11/2020

Date of acceptance of the article by the Editor: 28/03/2021

\author{
Dorota Wojtyto ${ }^{1}$ - orcid id: 0000-0003-2493-9808 \\ Joanna Michalik ${ }^{1}$ - orcid id: 0000-0002-6908-4527 \\ Michał Pałęga ${ }^{1}$ - orcid id: 0000-0002-2779-431X \\ Mina Angelova ${ }^{2}$ - orcid id: 0000-0002-1094-6356 \\ ${ }^{1}$ Czestochowa University of Technology, Poland \\ 2 University of Plovdiv Paisii Hilendarski, Bulgaria
}

\begin{abstract}
The focus of the paper is to identify risks in various areas of operation of a selected trade and production company. The risks primarily referred to threats that had direct or indirect impact on the functioning of the organisation, thence the causes of their occurrence and effects are determined. Identification of individual risks is made based on analyses of internal and external context of the enterprise. In this study, over thirty key risks were identified, in the operational and strategic area, which is related to the taking of immediate action. The final stage of the paper includes preparation of control mechanisms allowing for minimisation or elimination of the discovered risks.
\end{abstract}

Keywords: organisation context, threats, risk management, risk identification, risk analysis, risk assessment, control mechanisms.

\section{INTRODUCTION}

Risk management is currently an area of science and a realm of operation of various organisations which acquires increasing significance due to the essence of the broadly understood safety (Monkiewicz and Gąsiorkiewicz, 2010). Enterprises, institutions, and other organisational units that implement tasks in risk management are more aware of the opportunities and threats in their immediate and more distant environment and thus become capable of efficiently minimising the risk of failure and maximising the intended outcomes and profits (Knosala, 2018). Thus, they take care of their continuous development and safety and implement the agreed strategy better (Niciejewska and Kiriliuk, 2020; Niciejewska and Obrecht, 2020; Nikolova-Alexieva et al., 2018; Woźny, 2020).

Risk management primarily relies on performance of an efficient risk management process. It comprises several consecutive (or parallel) stages, such as: determination of the organisation's context and thus delineation of risk management goals, risk identification, risk analysis, risk assessment, reaction to risk, control, and communication. The aim of the current study is to identify the quality of risk management policies and actions implemented by an enterprise. Thus, the object of 
the study is a production and trade company that is in the Śląskie Province, Poland. The research was carried out in the third and the fourth quarter of 2020 (i.e. in June 2020 and in November 2020). The methodology is of a survey descriptive type and a broad range of research methods are used to successfully achieve the tasks and goals of the study. As a result, an identification of risks occurring along with causes, effects and control mechanisms are implemented.

Based on a literature review in the field, the first stage of risk management process refers to the designation of all aspects of an organisation's operation, which may be susceptible to the occurrence of threats. Subsequently, identification of potential risk factors is made and areas that they may refer to. Threats are characterised and the causes and effects (consequences) which they can lead to are determined (Wróbel, 2015). The third step is proper analysis of risk consisting in determining its value (probability, effects or additionally others). In the risk assessment it is necessary to specify whether the calculated level of risk fulfils the terms of acceptability or not. If the assessment indicates that the risk occurs on a non-acceptable level or a conditionally acceptable level, then it is necessary to determine the modes of handling such risk. Reaction to risk is a stage that consists in implementation of preventive activities or completely new control mechanisms. This is a stage during which costs of implementation of safeguarding measures are planned and the date of their performance, as well as the team of persons who will be responsible for such tasks. The penultimate stage is efficient communication among all interested entities.

On the other hand, monitoring is a stage in the risk management process that occurs in parallel with other stages and is carried out on a practically ongoing basis. It comprises monitoring of threats, assessment of implemented ex-post activities, as well new formation of the process. Individual stages of the risk management process require application of proper methodology and thus methods, techniques and tools that enable its performance. The selection of methodology is free and adjusted to the specific nature of a given company and its profile of operation (Jajuga, 2007; Kaczmarek, 2010; Oxford Advanced Learner's Dictionary, 2010).

The paper is structured as follows: following the introduction, in the second part is described the research methodology. This analysis paves the way for the third part, consisting in identification of risks in a company and compilation of control mechanisms. The fourth part stresses on the results and discussion based on the research. The article closes with summary and conclusions in the field of risk identification.

\section{RESEARCH METHODOLOGY}

The studied enterprise is a production and trade company that is in the Sląskie Province, Poland. The company's core activity is water jet cutting and laser cutting. The orders are performed for economic entities (very small and very large ones), as well as for retail clients. The method of cutting is intended for single-piece production, short-series production and processing of materials that are difficult to handle with other technologies. The performed service is dedicated to a broad group of recipients, e.g., manufacturers of machines and technological lines in the food industry, producers of machines and devices for mining and energy industry, producers of fittings, producers of laboratories, as well as the advertising industry, arms industry, construction industry, etc. 
The water jet cutting technology belongs to one of the most environmentally friendly technologies. It does not emit harmful vapours, heat, or waste. Additionally, it makes use of natural materials, clean water, and electricity. The company's competitive advantage is the fact that it holds a permit of the Ministry of Internal Affairs and Administration for performance of activities around production and trading in products and technology for military or police use. This is related to multiple opportunities, as well as threats, which will be discussed in a further part of this study. The company holds a certified quality system according to the EN-ISO 9001:2009 standard and successfully completes annual audits. The company has held the EN ISO 9001:2000 certificate since 2008 it is annually confirmed by the TUV Nord Cert GmbH audit. Furthermore, it holds the BISNODE Business Reliability Certificate of 2015 and Złoty Płatnik Certificate from 2015 - Euler Hermes.

For the purposes of this paper, the studies were carried out in the third and the fourth quarter of 2020 and its results will be used for further analysis and assessment of risk and performance of a holistic risk management process in the studied company with the aim of implementing a system compliant with the ISO 31000 Risk Management Principles and Guidelines System.

The study methodology comprised verification of the company's documents, a discussion, an interview, as well as a control list prepared with the employees of individual company divisions. Three main stages of the risk management process were completed, namely determination of the organisation's context, identification of risks and reaction to risk. Statistical data were used along with other information deriving from main areas of the company's operation: finances, production, sale and marketing, quality management and HR resources management in the company, strategic management.

\section{DISCUSSION AND RESULTS}

The first stage of the study was to determine the internal and external context of the studied enterprise. The internal environment referred to such areas of the company's operation as: mission, vision, values, management, organisational structures, roles and responsibilities of the company's personnel, strategies, goals, policy, organisational culture, standards, guidelines and models accepted by the organisation, opportunities, resources and knowledge (e.g. capital, time, people, intellectual property, processes, systems and technologies), data, information systems and flow of information, relations with internal stakeholders, taking into account their remarks and values, as well as contractual relations and obligations. On the other hand, the external context consisted in analysis of the following range: social, cultural, political, legal, regulatory, financial, technological, economic, and environmental factors, international, domestic, regional, and local ones, key factors and tendencies affecting the organisation's goals, contractual relations and obligations. With respect to the above, the following elements were distinguished, which may generate risks, but also opportunities for the company's development:

- servicing of economic entities (large and small) along with retail clients;

- price and quality of products, quality of provided services;

- longest experience in Poland in the water jet cutting technology;

- observance of top payment standards;

- engagement and cooperation of employees;

- customer servicing; 
- formalised organisational structure, preparation of scopes of obligations, employees' responsibilities and rights;

- responsibilities and rights of the Quality Management System Representative;

- democratic style of management;

- profitability of the company;

- sourcing new clients;

- zero complaint level;

- the company's development (maintenance of $100 \%$ employment, proper management of financial resources, launching of the abrasive recycling system);

- strictly defined work organisation (assignment of tasks and control of their correct performance);

- regular team meetings (briefings);

- counteracting mobbing at the workplace;

- integration meetings and company trips;

- implementation of the PN-EN ISO 9001:2009 standard;

- license for sub-systems and elements of military or police-use products;

- documented procedures, instructions;

- company secret;

- modern machines and devices - cutting plotters (water, laser) with a wide range of application;

- computer equipment with specialist software;

- the company's financial capital (funds accumulated on the bank account and in the cash register);

- subsidies from the European Union (EU funds);

- IT systems: Soft 4 Sale (management), IGEMS (water cutting design), TRU TOPS (laser design);

- databases: employees, clients, suppliers and other contracting partners;

- internal communication with employees (internal management, system documentation, trainings, periodical personnel meetings);

- contracts and liabilities;

- exchange of know-how;

- tax relief;

- inflation, unemployment;

- natural environment and external catastrophic threats;

- costs of labour, energy and transport;

- level of skills of the engineering and technical personnel, qualifications and experience of personnel;

- demand on the side of the army and police;

- threat on the side of competition;

- technological stability;

- possibility of service differentiation;

- dependence of certain services on the supply of abrasive.

Among most important factors of the internal and external environment that affect the functioning of the studied company are these which belong to the relations with clients (demand on the side of key buyers - the army and the police) and suppliers, competition, modern and costly technology, quality of provided services, safety systems, demand for personnel, as well as economic factors, legal and political ones, as well as factors related to the natural threats. At the time of current events related to 
the international COVID-19 coronavirus pandemic, there are also important factors in which the company must function in new, adverse conditions, which generates new threats.

One can look for opportunities and threats in every one of the above-listed elements of the company's environment. Given the fact that there are many of them, risks identified on such basis were aggregated. In relation to this, only these were selected that pose the greatest problem on the strategic and operational level of the organisation, as well as these that require priority activities (in the first place, activities minimising and eliminating the level of risk are taken about them) and they are presented in Table 1.

Table1

Identification of risks occurring in the studied enterprise along with control mechanisms

\begin{tabular}{|c|c|c|c|c|}
\hline № & Risks & Causes & Effects & Control mechanisms \\
\hline 1. & $\begin{array}{l}\text { Coronavirus } \\
\text { (COVID-19) } \\
\text { pandemic }\end{array}$ & $\begin{array}{l}\text { Global } \\
\text { emergence of a } \\
\text { virus which is a } \\
\text { threat to } \\
\text { people's health } \\
\text { and lives }\end{array}$ & $\begin{array}{l}\text { Lockdown, } \\
\text { suspension of } \\
\text { business, } \\
\text { downsized } \\
\text { production, loss of } \\
\text { financial liquidity, } \\
\text { loss of income and } \\
\text { key clients }\end{array}$ & $\begin{array}{l}\text { Activities minimising the } \\
\text { spread of virus, } \\
\text { adherence to the } \\
\text { recommendations of the } \\
\text { Chief Sanitary Inspector } \\
\text { and the Ministry of } \\
\text { Health, observance of } \\
\text { safety procedures, } \\
\text { procurement of financing } \\
\text { from the state anti-crisis } \\
\text { shield programme, } \\
\text { governmental subsidies }\end{array}$ \\
\hline 2. & $\begin{array}{l}\text { Lower } \\
\text { consumption } \\
\text { of water and } \\
\text { electricity }\end{array}$ & $\begin{array}{l}\text { Problems } \\
\text { related to the } \\
\text { transfer of } \\
\text { utilities on the } \\
\text { side of suppliers }\end{array}$ & $\begin{array}{l}\text { Halted production, } \\
\text { production losses }\end{array}$ & $\begin{array}{l}\text { Securing lack of water for } \\
8 \text { hours: a } 1000 \mathrm{~L} \text { Mauzer } \\
\text { container, contracts with } \\
\text { suppliers, negotiation of } \\
\text { prices }\end{array}$ \\
\hline 3. & $\begin{array}{l}\text { Increased } \\
\text { competition on } \\
\text { the side of } \\
\text { large entities }\end{array}$ & $\begin{array}{l}\text { Significant } \\
\text { position of } \\
\text { competitors on } \\
\text { the market, } \\
\text { diversification of } \\
\text { services by } \\
\text { competitors, } \\
\text { emergence of } \\
\text { new competitors }\end{array}$ & $\begin{array}{l}\text { Reduced demand, } \\
\text { loss of a part of } \\
\text { clients }\end{array}$ & $\begin{array}{l}\text { Diversification of provided } \\
\text { services, sourcing new } \\
\text { clients, filing applications } \\
\text { for the funding of } \\
\text { innovative activity of } \\
\text { economic entities, } \\
\text { marketing activities }\end{array}$ \\
\hline 4. & $\begin{array}{l}\text { Foreign } \\
\text { exchange } \\
\text { fluctuations }\end{array}$ & $\begin{array}{l}\text { The state's } \\
\text { financial policy }\end{array}$ & $\begin{array}{l}\text { Increase in the } \\
\text { price of offered } \\
\text { services, reduced } \\
\text { demand, loss of a } \\
\text { part of clients, } \\
\text { reduction of profit }\end{array}$ & $\begin{array}{l}\text { Possibility of dividing } \\
\text { streams of revenues or } \\
\text { foreign exchange } \\
\text { payments into minor } \\
\text { portions, paid in various } \\
\text { periods, possibility of sale } \\
\text { or purchase of foreign } \\
\text { currency in forward } \\
\text { transactions }\end{array}$ \\
\hline
\end{tabular}




\begin{tabular}{|c|c|c|c|c|}
\hline № & Risks & Causes & Effects & Control mechanisms \\
\hline 5. & $\begin{array}{l}\text { Lack of } \\
\text { financial } \\
\text { liquidity }\end{array}$ & $\begin{array}{l}\text { Long payment } \\
\text { deadlines from } \\
\text { suppliers }\end{array}$ & $\begin{array}{l}\text { Halted production, } \\
\text { loss of a part of } \\
\text { clients, loss of the } \\
\text { company's image }\end{array}$ & $\begin{array}{l}\text { Change in the terms of } \\
\text { payment transactions }\end{array}$ \\
\hline 6. & $\begin{array}{l}\text { Increase in } \\
\text { fixed and } \\
\text { variable costs }\end{array}$ & $\begin{array}{l}\text { Inflation, } \\
\text { increase in } \\
\text { labour costs, } \\
\text { energy, } \\
\text { transport, raw } \\
\text { materials and } \\
\text { materials }\end{array}$ & $\begin{array}{l}\text { Increase in the } \\
\text { price of offered } \\
\text { services, reduced } \\
\text { demand, loss of a } \\
\text { part of clients, lack } \\
\text { of profitability }\end{array}$ & $\begin{array}{l}\text { Selection of optimum } \\
\text { cutting parameters, } \\
\text { optimum cut-out of } \\
\text { materials, savings, } \\
\text { change of suppliers, } \\
\text { sourcing new clients, } \\
\text { applications for financing } \\
\text { business activity as part } \\
\text { of EU projects and } \\
\text { subsidies }\end{array}$ \\
\hline 7. & $\begin{array}{l}\text { Economic } \\
\text { problems of } \\
\text { major clients }\end{array}$ & $\begin{array}{l}\text { Financial policy } \\
\text { of the company, } \\
\text { economic } \\
\text { factors }\end{array}$ & $\begin{array}{l}\text { Loss of } \\
\text { cooperation, lack of } \\
\text { clients' solvency, } \\
\text { drop in profits, drop } \\
\text { in financial liquidity, } \\
\text { court cases }\end{array}$ & $\begin{array}{l}\text { Crediting of orders, } \\
\text { deferral of orders and } \\
\text { payments, discounts and } \\
\text { price reductions, sourcing } \\
\text { new clients }\end{array}$ \\
\hline 8. & $\begin{array}{l}\text { Economic } \\
\text { situation }\end{array}$ & $\begin{array}{l}\text { The country's } \\
\text { economic } \\
\text { policy, external } \\
\text { determinants }\end{array}$ & $\begin{array}{l}\text { Drop in demand for } \\
\text { products and } \\
\text { services, loss of } \\
\text { revenues, lack of } \\
\text { qualified personnel }\end{array}$ & $\begin{array}{l}\text { Adjustment of activities to } \\
\text { the current economic } \\
\text { situation }\end{array}$ \\
\hline 9. & $\begin{array}{l}\text { Technical } \\
\text { failures, } \\
\text { construction } \\
\text { catastrophes }\end{array}$ & $\begin{array}{l}\text { Incorrect } \\
\text { maintenance of } \\
\text { machines, } \\
\text { devices and } \\
\text { construction } \\
\text { facilities, } \\
\text { exceeding } \\
\text { authorisations, } \\
\text { failure to } \\
\text { observe } \\
\text { provisions and } \\
\text { safety } \\
\text { procedures, } \\
\text { lack of risk } \\
\text { analysis }\end{array}$ & $\begin{array}{l}\text { Direct threat to } \\
\text { human health and } \\
\text { life, panic, } \\
\text { necessity to } \\
\text { evacuate people, } \\
\text { disruptions in } \\
\text { transport and } \\
\text { communication, } \\
\text { disruptions in } \\
\text { operation of the } \\
\text { gas grid, electricity } \\
\text { and heat network, } \\
\text { destruction of the } \\
\text { company's } \\
\text { property }\end{array}$ & $\begin{array}{l}\text { Insurance, observance of } \\
\text { safety principles, proper } \\
\text { use of machines, devices } \\
\text { and construction facilities, } \\
\text { performance of the risk } \\
\text { management process }\end{array}$ \\
\hline 10. & $\begin{array}{l}\text { Theft/ loss of } \\
\text { material and } \\
\text { financial } \\
\text { assets }\end{array}$ & $\begin{array}{l}\text { Crime, burglary, } \\
\text { fraud, lack of } \\
\text { implemented } \\
\text { safety } \\
\text { procedures }\end{array}$ & $\begin{array}{l}\text { Financial losses, } \\
\text { breaks in } \\
\text { production }\end{array}$ & $\begin{array}{l}\text { Technical safeguards, } \\
\text { insurance, security } \\
\text { services, security } \\
\text { procedures, alarm } \\
\text { systems, monitoring, } \\
\text { roles and responsibilities } \\
\text { of key employees }\end{array}$ \\
\hline 11. & $\begin{array}{l}\text { Destruction of } \\
\text { resources }\end{array}$ & $\begin{array}{l}\text { Crime, burglary, } \\
\text { force majeure } \\
\text { (natural } \\
\text { disasters) }\end{array}$ & $\begin{array}{l}\text { Financial losses, } \\
\text { loss of key } \\
\text { information }\end{array}$ & $\begin{array}{l}\text { Insurance, protection from } \\
\text { burglary, securing of } \\
\text { materials, protection of } \\
\text { resources, adherence to }\end{array}$ \\
\hline
\end{tabular}




\begin{tabular}{|c|c|c|c|c|}
\hline № & Risks & Causes & Effects & Control mechanisms \\
\hline & & & & $\begin{array}{l}\text { safety principles, } \\
\text { implementation of security } \\
\text { systems }\end{array}$ \\
\hline 12. & $\begin{array}{l}\text { Lack of } \\
\text { resources on } \\
\text { the market }\end{array}$ & $\begin{array}{l}\text { Economic and } \\
\text { foreign policy of } \\
\text { the country }\end{array}$ & $\begin{array}{l}\text { Halted production, } \\
\text { no possibility to } \\
\text { provide services, } \\
\text { loss of a part of } \\
\text { clients, loss of } \\
\text { company image }\end{array}$ & $\begin{array}{l}\text { Stock of standard } \\
\text { materials or most } \\
\text { frequently used materials, } \\
\text { searching for alternative } \\
\text { suppliers of resources }\end{array}$ \\
\hline 13. & $\begin{array}{l}\text { Violation of } \\
\text { information } \\
\text { security }\end{array}$ & $\begin{array}{l}\text { Lack of } \\
\text { knowledge and } \\
\text { trainings for } \\
\text { employees, lack } \\
\text { of safeguards } \\
\text { and data } \\
\text { protection; } \\
\text { failure to } \\
\text { implement } \\
\text { information } \\
\text { security } \\
\text { procedures, } \\
\text { imprudence of } \\
\text { employees }\end{array}$ & $\begin{array}{l}\text { Loss of key } \\
\text { information, } \\
\text { violation of } \\
\text { company secret }\end{array}$ & $\begin{array}{l}\text { Implementation and } \\
\text { observance of security } \\
\text { principles, training and } \\
\text { teaching of employees, IT } \\
\text { safeguards, security } \\
\text { audits, employee } \\
\text { trainings, introduction of } \\
\text { information security } \\
\text { system }\end{array}$ \\
\hline 14. & $\begin{array}{l}\text { Irregularities in } \\
\text { the use of EU } \\
\text { funds }\end{array}$ & $\begin{array}{l}\text { Lack of } \\
\text { supervision and } \\
\text { control }\end{array}$ & $\begin{array}{l}\text { Liquidated } \\
\text { damages, return of } \\
\text { funds, incorrect } \\
\text { use of available } \\
\text { assets }\end{array}$ & $\begin{array}{l}\text { Division of obligations, } \\
\text { training and improvement } \\
\text { of knowledge, internal } \\
\text { control system, analysis } \\
\text { of risk in the area of } \\
\text { financial abuse, ethical } \\
\text { conduct }\end{array}$ \\
\hline 15. & $\begin{array}{l}\text { Difficulties } \\
\text { with sourcing } \\
\text { new clients } \\
\text { and retaining } \\
\text { current ones }\end{array}$ & $\begin{array}{l}\text { Consumer } \\
\text { habits of clients, } \\
\text { competition on } \\
\text { the market }\end{array}$ & $\begin{array}{l}\text { Sourcing clients via } \\
\text { competitors, } \\
\text { reduction of prices } \\
\text { of services in order } \\
\text { to maintain } \\
\text { production and } \\
\text { financial activities }\end{array}$ & $\begin{array}{l}\text { Building relations with } \\
\text { clients, quick reaction to } \\
\text { the clients' needs, proper } \\
\text { choice of the target group } \\
\text { of clients, personal } \\
\text { approach to clients, } \\
\text { professional } \\
\text { communication, extended } \\
\text { marketing activities. }\end{array}$ \\
\hline 16. & $\begin{array}{l}\text { Activities for } \\
\text { the sake of the } \\
\text { natural } \\
\text { environment }\end{array}$ & $\begin{array}{l}\text { Use of garnet } \\
\text { for production }\end{array}$ & $\begin{array}{l}\text { Environmental } \\
\text { pollution, high } \\
\text { costs of garnet } \\
\text { utilisation }\end{array}$ & $\begin{array}{l}\text { Introduction of abrasive } \\
\text { recovery system }\end{array}$ \\
\hline 17. & $\begin{array}{l}\text { High } \\
\text { temperature } \\
\text { resulting in } \\
\text { overheating of } \\
\text { machines }\end{array}$ & $\begin{array}{l}\text { Weather factors } \\
\text { - hot summer }\end{array}$ & $\begin{array}{l}\text { Failures, } \\
\text { suspension of } \\
\text { production, high } \\
\text { costs of production, } \\
\text { financial losses }\end{array}$ & $\begin{array}{l}\text { Heat disposal (triple } \\
\text { circulation system) }\end{array}$ \\
\hline 18. & $\begin{array}{l}\text { Substitute } \\
\text { (plasma } \\
\text { cutting) }\end{array}$ & $\begin{array}{l}\text { Development of } \\
\text { plasma cutting } \\
\text { technology, }\end{array}$ & $\begin{array}{l}\text { New possibilities } \\
\text { and opportunities } \\
\text { for the company, }\end{array}$ & $\begin{array}{l}\text { Laser cutting is applied in } \\
\text { the cutting of precise } \\
\text { elements with complex }\end{array}$ \\
\hline
\end{tabular}




\begin{tabular}{|c|c|c|c|c|}
\hline № & Risks & Causes & Effects & Control mechanisms \\
\hline & & $\begin{array}{l}\text { scientific } \\
\text { accomplishment } \\
\mathrm{s}\end{array}$ & $\begin{array}{l}\text { subsidies for } \\
\text { innovative activities }\end{array}$ & $\begin{array}{l}\text { shapes, with small } \\
\text { diameters (e.g. inner } \\
\text { angles, loops, arcs, } \\
\text { combs) }\end{array}$ \\
\hline 19. & $\begin{array}{l}\text { Insufficient } \\
\text { competence } \\
\text { and errors of } \\
\text { employees }\end{array}$ & $\begin{array}{l}\text { Lack of } \\
\text { evaluation of } \\
\text { employees' } \\
\text { competence, } \\
\text { inefficient } \\
\text { system of } \\
\text { education, } \\
\text { recruitment of } \\
\text { employees } \\
\text { without } \\
\text { experience, lack } \\
\text { of trainings }\end{array}$ & $\begin{array}{l}\text { High employee } \\
\text { fluctuation, } \\
\text { excessive errors, } \\
\text { delays in service } \\
\text { performance, } \\
\text { breaks in } \\
\text { production, } \\
\text { additional costs, } \\
\text { financial and } \\
\text { material losses }\end{array}$ & $\begin{array}{l}\text { Proper employee } \\
\text { recruitment and selection, } \\
\text { on-boarding trainings, } \\
\text { cooperation with } \\
\text { secondary schools in the } \\
\text { area of education, } \\
\text { refresher trainings, } \\
\text { ongoing development and } \\
\text { self improvement, } \\
\text { correction and adjustment } \\
\text { of labour utilisation, } \\
\text { replacement }\end{array}$ \\
\hline 20. & $\begin{array}{l}\text { Inefficient } \\
\text { system of } \\
\text { information } \\
\text { flow }\end{array}$ & $\begin{array}{l}\text { Lack of efficient } \\
\text { system of } \\
\text { information flow, } \\
\text { lack of } \\
\text { communication } \\
\text { trainings }\end{array}$ & $\begin{array}{l}\text { Excessive errors, } \\
\text { delays in service } \\
\text { performance, } \\
\text { breaks in } \\
\text { production }\end{array}$ & $\begin{array}{l}\text { Introduction of an } \\
\text { integrated information } \\
\text { flow and exchange } \\
\text { system among the } \\
\text { company's units }\end{array}$ \\
\hline 21. & $\begin{array}{l}\text { Lack of } \\
\text { employees' } \\
\text { engagement }\end{array}$ & $\begin{array}{l}\text { Incorrect } \\
\text { employee } \\
\text { incentive } \\
\text { scheme, } \\
\text { conflicts in } \\
\text { teams, low } \\
\text { remuneration }\end{array}$ & $\begin{array}{l}\text { Excessive errors, } \\
\text { delays in service } \\
\text { performance, } \\
\text { breaks in } \\
\text { production, } \\
\text { additional costs, } \\
\text { termination of } \\
\text { employment } \\
\text { contracts }\end{array}$ & $\begin{array}{l}\text { Employee motivation, fair } \\
\text { remuneration system, } \\
\text { system of prizes and } \\
\text { penalties }\end{array}$ \\
\hline 22. & $\begin{array}{l}\text { Accidents at } \\
\text { work }\end{array}$ & $\begin{array}{l}\text { Failure to } \\
\text { adhere to the } \\
\text { OHS principles, } \\
\text { incorrect } \\
\text { safeguarding of } \\
\text { machines and } \\
\text { devices, failure } \\
\text { to use personal } \\
\text { protection } \\
\text { equipment, } \\
\text { occurrence of } \\
\text { hazardous and } \\
\text { detrimental } \\
\text { factors in the } \\
\text { labour } \\
\text { environment }\end{array}$ & $\begin{array}{l}\text { Employee } \\
\text { absenteeism, } \\
\text { halted production, } \\
\text { additional costs, } \\
\text { loss of image }\end{array}$ & $\begin{array}{l}\text { OHS principles, } \\
\text { employee trainings, } \\
\text { proper preparation of } \\
\text { work positions and } \\
\text { designation of hazardous } \\
\text { zones, application of } \\
\text { personal protection } \\
\text { equipment, limitation of } \\
\text { hazardous factors, } \\
\text { investments in new } \\
\text { technology, insurance, } \\
\text { adequate assessment of } \\
\text { professional risk }\end{array}$ \\
\hline
\end{tabular}




\begin{tabular}{|c|c|c|c|c|}
\hline № & Risks & Causes & Effects & Control mechanisms \\
\hline 23. & $\begin{array}{l}\text { No possibility } \\
\text { to enforce } \\
\text { liability with } \\
\text { respect to the } \\
\text { entrusted } \\
\text { property }\end{array}$ & $\begin{array}{l}\text { Lack of legal } \\
\text { regulations } \\
\text { pertaining to the } \\
\text { liability for the } \\
\text { entrusted } \\
\text { property, failure } \\
\text { to enforce the } \\
\text { law }\end{array}$ & $\begin{array}{l}\text { Excessive errors, } \\
\text { delays in service } \\
\text { performance, } \\
\text { breaks in } \\
\text { production, } \\
\text { additional costs, } \\
\text { termination of } \\
\text { employment } \\
\text { contracts }\end{array}$ & $\begin{array}{l}\text { Seeking damages } \\
\text { amicably or in court }\end{array}$ \\
\hline 24. & $\begin{array}{l}\text { Lack of } \\
\text { stability of } \\
\text { supplies }\end{array}$ & $\begin{array}{l}\text { Lack of } \\
\text { resources on } \\
\text { the market; } \\
\text { unstable } \\
\text { economic } \\
\text { situation, lack of } \\
\text { suppliers or } \\
\text { limited number } \\
\text { of suppliers, } \\
\text { disruptions in } \\
\text { timely supplies }\end{array}$ & $\begin{array}{l}\text { Lack of production } \\
\text { stock, financial and } \\
\text { production losses, } \\
\text { loss of clients }\end{array}$ & $\begin{array}{l}\text { Planning of deliveries in } \\
\text { advance, confirmation of } \\
\text { dates of delivery at the } \\
\text { tendering stage, safety } \\
\text { stocks, liquidated } \\
\text { damages for late } \\
\text { deliveries, reserve } \\
\text { suppliers }\end{array}$ \\
\hline 25. & $\begin{array}{l}\text { Monopolist } \\
\text { position of } \\
\text { suppliers }\end{array}$ & $\begin{array}{l}\text { Too few } \\
\text { suppliers on the } \\
\text { market, high } \\
\text { bargaining } \\
\text { power of } \\
\text { suppliers in the } \\
\text { sector }\end{array}$ & $\begin{array}{l}\text { Lack of availability } \\
\text { of production } \\
\text { materials, breaks in } \\
\text { production, delays } \\
\text { in service } \\
\text { performance }\end{array}$ & $\begin{array}{l}\text { Planning of deliveries in } \\
\text { advance, confirmation of } \\
\text { dates of delivery at the } \\
\text { tendering stage, safety } \\
\text { stocks, liquidated } \\
\text { damages for late } \\
\text { deliveries, reserve } \\
\text { suppliers }\end{array}$ \\
\hline 26. & Late deliveries & $\begin{array}{l}\text { Lack of } \\
\text { materials on the } \\
\text { market, } \\
\text { problems with } \\
\text { transport }\end{array}$ & $\begin{array}{l}\text { Break in } \\
\text { production, delays } \\
\text { in service } \\
\text { performance }\end{array}$ & $\begin{array}{l}\text { Planning of deliveries in } \\
\text { advance, confirmation of } \\
\text { dates of delivery at the } \\
\text { tendering stage, safety } \\
\text { stocks, liquidated } \\
\text { damages for late } \\
\text { deliveries, reserve } \\
\text { suppliers }\end{array}$ \\
\hline 27. & $\begin{array}{l}\text { Low quality of } \\
\text { raw materials }\end{array}$ & $\begin{array}{l}\text { Lack of criteria } \\
\text { to verify } \\
\text { suppliers }\end{array}$ & $\begin{array}{l}\text { Production } \\
\text { problems, low } \\
\text { quality of offered } \\
\text { products and } \\
\text { services, financial } \\
\text { losses }\end{array}$ & $\begin{array}{l}\text { Verification of supplies, } \\
\text { requirement of licenses; }\end{array}$ \\
\hline 28. & $\begin{array}{l}\text { Resistance of } \\
\text { employees, } \\
\text { unwillingness } \\
\text { to changes }\end{array}$ & $\begin{array}{l}\text { Lack of proper } \\
\text { motivation of } \\
\text { employees }\end{array}$ & $\begin{array}{l}\text { No possibility of } \\
\text { introduction }\end{array}$ & $\begin{array}{l}\text { Delivery of up-to-date } \\
\text { knowledge and } \\
\text { information about the } \\
\text { implemented changes, } \\
\text { presentation of benefits } \\
\text { from the introduced } \\
\text { changes, building a } \\
\text { feeling of security, } \\
\text { building correct }\end{array}$ \\
\hline
\end{tabular}




\begin{tabular}{|c|c|c|c|c|}
\hline № & Risks & Causes & Effects & Control mechanisms \\
\hline & & & & $\begin{array}{l}\text { interpersonal relations, } \\
\text { participation and } \\
\text { motivation of employees, } \\
\text { engagement of } \\
\text { employees, planning of } \\
\text { changes }\end{array}$ \\
\hline 29. & $\begin{array}{l}\text { Failures of } \\
\text { machines and } \\
\text { devices }\end{array}$ & $\begin{array}{l}\text { Obsolete } \\
\text { machines and } \\
\text { devices, lack of } \\
\text { maintenance } \\
\text { and inspections, } \\
\text { incorrect } \\
\text { exploitation }\end{array}$ & $\begin{array}{l}\text { Light or severe } \\
\text { bodily injuries, } \\
\text { even death, } \\
\text { complete } \\
\text { destruction of a } \\
\text { device, production } \\
\text { losses }\end{array}$ & $\begin{array}{l}\text { Inspections, maintenance, } \\
\text { use in compliance with } \\
\text { user's manuals, remote } \\
\text { removal of failures }\end{array}$ \\
\hline 30. & $\begin{array}{l}\text { Incorrect } \\
\text { choice of } \\
\text { cutting } \\
\text { parameters }\end{array}$ & $\begin{array}{l}\text { Employee's } \\
\text { errors }\end{array}$ & $\begin{array}{l}\text { Losses in } \\
\text { production, } \\
\text { destruction of } \\
\text { materials, financial } \\
\text { losses, loss of the } \\
\text { company's image }\end{array}$ & $\begin{array}{l}\text { Preparation of material } \\
\text { inventories, experience of } \\
\text { programmers }\end{array}$ \\
\hline 31. & $\begin{array}{l}\text { Disruptions in } \\
\text { supplies of } \\
\text { energy and } \\
\text { water }\end{array}$ & $\begin{array}{l}\text { Failure, strains } \\
\text { in consumption, } \\
\text { environmental } \\
\text { issues }\end{array}$ & $\begin{array}{l}\text { Break in } \\
\text { production, } \\
\text { financial losses }\end{array}$ & $\begin{array}{l}\text { Securing lack of water for } \\
8 \text { hours: } 1000 \text { L Mauzer } \\
\text { container }\end{array}$ \\
\hline 32. & $\begin{array}{l}\text { Incorrect } \\
\text { drawings } \\
\text { provided by } \\
\text { the client }\end{array}$ & $\begin{array}{l}\text { The client's lack } \\
\text { of experience, } \\
\text { errors }\end{array}$ & $\begin{array}{l}\text { Losses in } \\
\text { production, } \\
\text { destruction of } \\
\text { materials, delays in } \\
\text { service } \\
\text { performance } \\
\end{array}$ & $\begin{array}{l}\text { Checking dimensions and } \\
\text { offering details with } \\
\text { dimensions, approval of } \\
\text { offers by the client }\end{array}$ \\
\hline 33. & $\begin{array}{l}\text { Lack of access } \\
\text { to data } \\
\text { necessary in } \\
\text { the production } \\
\text { process }\end{array}$ & $\begin{array}{l}\text { Incorrect } \\
\text { securing of } \\
\text { data, loss of } \\
\text { data, failure of } \\
\text { the ICT system } \\
\end{array}$ & $\begin{array}{l}\text { Break in } \\
\text { production, delays } \\
\text { in service } \\
\text { performance }\end{array}$ & $\begin{array}{l}\text { Archiving of data and } \\
\text { preparation of back-up } \\
\text { copies }\end{array}$ \\
\hline 34. & $\begin{array}{l}\text { Failure of the } \\
\text { IT system }\end{array}$ & $\begin{array}{l}\text { Lack of stable } \\
\text { operation of one } \\
\text { of the system } \\
\text { components, } \\
\text { technical errors } \\
\text { in the system, } \\
\text { natural } \\
\text { disasters, } \\
\text { intentional or } \\
\text { accidental } \\
\text { actions of man }\end{array}$ & $\begin{array}{l}\text { Break in } \\
\text { production, delays } \\
\text { in service } \\
\text { performance; } \\
\text { disruptions in } \\
\text { continuity of } \\
\text { operation, possible } \\
\text { loss of access to } \\
\text { data, data } \\
\text { confidentiality }\end{array}$ & $\begin{array}{l}\text { Audit of IT system and } \\
\text { implementation of } \\
\text { required changes, system } \\
\text { updates (implementation } \\
\text { of necessary extensions, } \\
\text { data archiving and } \\
\text { preparation of back-up } \\
\text { copies; anti-virus } \\
\text { systems, preparation and } \\
\text { implementation of security } \\
\text { policy) }\end{array}$ \\
\hline 35. & $\begin{array}{l}\text { Break-in into } \\
\text { the system }\end{array}$ & $\begin{array}{l}\text { Breaking of } \\
\text { safeguards, } \\
\text { incorrect system } \\
\text { configuration, } \\
\text { incorrect actions } \\
\text { of users }\end{array}$ & $\begin{array}{l}\text { Break in } \\
\text { production, delays } \\
\text { in service } \\
\text { performance; } \\
\text { disruptions in } \\
\text { continuity of }\end{array}$ & $\begin{array}{l}\text { Anti-virus software, } \\
\text { firewalls, authentication } \\
\text { (use of strong passwords, } \\
\text { passwords to routers and } \\
\text { other security systems) }\end{array}$ \\
\hline
\end{tabular}




\begin{tabular}{|c|l|l|l|l|}
\hline № & Risks & Causes & \multicolumn{1}{|c|}{ Effects } & Control mechanisms \\
\hline & & & $\begin{array}{l}\text { operation, possible } \\
\text { loss of access to } \\
\text { data, data } \\
\text { confidentiality }\end{array}$ & \\
& & & \\
\hline
\end{tabular}

Source: own study

Identification of risk is the second and essential element of the risk management process, underlying further analysis, assessment, and reaction to risk, whereas in a further perspective, it also concerns two stages of the process that occur in parallel (control and communication). Based on identification of risks in the studied company and analysis of Table 1, the following conclusions can be drawn:

1) pursuant to the analysis of the company's documents, carried out during interviews with the management and personnel, as well as on the basis of statistical and strategic analyses of the company, thirty-five main risks were identified which form a basis for implementation of a further risk management process;

2) the identified risks are primarily operational risks, related to the production process, as well as market risks, pertaining mainly to suppliers and resources, IT risks, risks for human resources, and recently also the external risk and the strategic risk;

3) major risks from the point of view of the company's profile of operation and further perspectives of its development are: risks directly related to the production process, given the generated financial losses, increased competition in the sector forcing the enterprise to take actions aimed at reduction of prices and increase in the quality of provided services, risks related to suppliers and clients, including risks related to the sourcing of new clients in difficult market conditions, risks related to the economic situation, economic problems, indirectly also related to the current state of the pandemic. Furthermore, an important role is played by risks related to the human factor on account of the problems with sourcing competent employees on the labour market, having specialist qualifications, ready to take innovative actions supported by new projects and external funds. Less important risks relate to machines and devices on account of use of a modern and safe technology and observance of basic safety principles, risks of accidents at work (no events were recorded), as well as risks related to information security (implemented information security systems, implementation of security policy) and ensuring high quality of provided services (given the implementation of ISO 9001 and its cyclical certification). It is worth drawing attention to the fact that a significant opportunity has appeared among risks: plasma cutting as a substitute activity, thanks to which the company has a possibility of conducting innovative activities and sourcing funds for development;

4) the most frequent causes of risk include: global threats, market determinants, increase in fixed costs, the state's economic policy, lack of qualified employees, errors of employees and lack of engagement in innovative activities of the company, price-quality ratio, problems with sourcing clients and new suppliers, high requirements of clients with respect to prices and competition in the sector, low quality of raw materials and lack of resources; 
5) the most frequently occurring effects of identified risks include: halts in production and disruptions in continuous operation of the company, lack of financial liquidity, financial losses, loss of clients due to increased competition and increased prices of services, and even - in a pessimistic scenario - suspension of the company's operation.

6) the most important control mechanisms include: application of safety procedures, ensuring continuity of operation, insurance, safeguarding of stocks, diversification of operation, among others via innovative activities and sourcing external financing, changes in terms of payment transactions, sourcing new clients and suppliers, introduction of systematic training for employees, as well as holistic implementation of the risk management process in the enterprise;

7) activities minimising or eliminating risks (control mechanisms) are mainly focused on elimination of causes of specific risks and also the resulting effects of threats. However, this is related to a thorough analysis and assessment of risk, using determination of values of risk parameters (probability and effects) with the application of adequate quantitative or quantitative and qualitative methodology (e.g. a risk matrix).

\section{CONCLUSION}

Summing up the discussion pertaining to the identification of risks in the examined enterprise, it may be concluded that the company is currently in an uncertain situation as far as making strategic decisions in the face of external determinants is concerned. As follows from the organisation's context, although there are more internal factors than external ones, their impact is less significant when the potential effects are concerned. In this study, over thirty key risks were identified, in the operational and strategic area, which is related to the taking of immediate action.

The paper presents only three stages of the risk management process, thus the next step in this research project will be preparation of a detailed analysis and risk assessment with the application of proper methodology relying on risk parameters, such as probability (or the level of impact on the organisation) and its effects. An interesting and, at the same time, a practical approach would also be considering potential opportunities that may appear in the company, with respect to the taking of innovative actions, which are currently a very important area of the company's development.

Given the occurrence of a significant number of aggregated risks in the studied company, it is also necessary to make decisions about the introduction of the 31000 standard and implementation of the risk management system, as all areas of the company's operation are engaged in risk generation (FERMA 2003, AIRMIC Risk Management ISO 31000:2017, Standard AS/NZS 4360:2004). Implementation of risk management standards minimises such risk, allowing for integration of the remaining systems (e.g. ISO 9001, or 2700). The company is continually developing and looking for new intellectual potential; it implements new technologies and plans further diversification, thus appearance of new threats and opportunities for the organisation is becoming an inevitable issue. The paper does not exhaust the issue of risk management process; it is an open aspect and requires further analysis and assessment of the problems presented in the work. 


\section{ACKNOWLEDGEMENTS}

The participation of M. Angelova, PhD, in the paper is part of a project № КП-06 К210, funded by Bulgarian National Science Fund.

\section{REFERENCES}

AIRMIC Risk Management

ISO 31000:2017.

FERMA, 2003. Standard zarządzania ryzykiem.

Jajuga, K., 2007. Zarządzanie ryzykiem, PWN, Warsaw.

Kaczmarek, T., 2010. Zarządzanie ryzykiem. Ujęcie interdyscyplinarne, Difin, Warsaw.

Knosala, R., Deptuła, A., 2018. Ocena ryzyka wdrażania innowacji, PWE, Warsaw.

Monkiewicz, J.N., Gąsiorkiewicz, L., 2010. Zarządzanie ryzykiem działalności organizacji, C.H. Beck, Warsaw.

Niciejewska, M., Kiriliuk, O., 2020. Occupational health and safety management in "small size" enterprises, with particular emphasis on hazards identification, Production Engineering Archives, 26(4), 195-201. DOI: 10.30657/pea.2020.26.34.

Niciejewska, M., Obrecht, M., 2020. Impact of Behavioral Safety (Behavioural-Based Safety - BBS) on the Modification of Dangerous Behaviors in Enterprises, System Safety: Human - Technical Facility - Environment, 2(1), 324-332. DOI: 10.2478/czoto-2020-0040

Nikolova-Alexieva, V., Mihova, T., Angelova, M., Bakardzhieva, M., 2018. Increasing organisation's performance by driving business agility and operational excellence through BPM, Proceedings of the $15^{\text {th }}$ International Conference on Business Economics "Challenges to Industrial Growth", 1, 43-54; 12-14 October $2018,70^{\text {th }}$ Anniversary of the Industrial Business Department of the University of National and World Economy, Sofia, Bulgaria Orange Book - Management of Risk, HM Treasury, October 2004, 9.

Oxford Advanced Learner's Dictionary, 2010. Oxford University Press.

Standard AS/NZS 4360:2004.

Woźny, A., 2020. Selected problems of managing work safety - case study. Production Engineering Archives, 26(3), 99-103. DOI: 10.30657/pea.2020.26.20

Wróbel, R., et al., 2015. Metodyka analizy ryzyka do stosowania na różnych poziomach zarzadzania kryzysowego, Skomra W. (Ed.), Metodyka oceny ryzyka na potrzeby systemu zarządzania kryzysowego RP, BEL Studio Sp. z o.o., Warsaw. 